\title{
Reliving South African Apartheid History in a Classroom: Using Vuyisile Mini’s Protest Songs ${ }^{1}$
}

\author{
Vuyisile Msila \\ Department of Educational Leadership and Management, College of Education, \\ University of South Africa (UNISA), Pretoria, South Africa \\ Email: msilavt@unisa.ac.za
}

Received October $30^{\text {th }}$, 2013; revised November $30^{\text {th }}$, 2013; accepted December $7^{\text {th }}$, 2013

\begin{abstract}
Copyright () 2013 Vuyisile Msila. This is an open access article distributed under the Creative Commons Attribution License, which permits unrestricted use, distribution, and reproduction in any medium, provided the original work is properly cited. In accordance of the Creative Commons Attribution License all Copyrights (c) 2013 are reserved for SCIRP and the owner of the intellectual property Vuyisile Msila. All Copyright (C 2013 are guarded by law and by SCIRP as a guardian.
\end{abstract}

\begin{abstract}
Many history pupils in South African classrooms study history in second or third language. This creates a number of problems for pupils who have to struggle with the language of learning and teaching as they grapple with historical events. This study sought to examine the impact of the protest song in the teaching of South African (struggle) history. The researcher employed qualitative research methods to investigate one teacher's practice in her two history classes. She used struggle stalwart and composer, Vuyisile Mini's compositions in facilitating teaching. The songs were either played from an audiotape or the teacher taught the class lyrics of some songs for the pupils to sing. Both the pupils and their teacher concurred that music played a crucial role in the classroom. The pupils also pointed out that music made them to remember historical events. The teacher stated that she wanted the pupils to be able to think critically as they constructed knowledge during the lessons. Moreover, in line with literature, the history classes were able to use cultural memory for critical learning. The methods used in the class were also able to make the pupils transfer learning to other situations. Conclusions illustrate that effective teachers will always seek creative ways to engage pupils in classrooms and music is one of these. Utilizing creative ways continuously is the crux of effective teaching and learning.
\end{abstract}

Keywords: Apartheid; Collective Memory; Heritage; Critical Thinking; Creative Teaching

\section{Introduction}

Long before they start their schooling careers, children learn to sing. The radio, the television and religious groups are some of the powerful sources of teaching the pre-schoolers to sing. However, music appears to be less used in South African schools after the initial grades. Schools around the world though have been using music for decades especially in second language classrooms where it is perceived as crucial in developing the cognitive aspects (Engh, 2013; Heyworth, 2013). Furthermore, Engh (2013) contends that music breaks the boundaries between the various communities that pupils belong to. This author maintains that life outside the classroom is filled with music and it is justifiable to consider it as a non-traditional teaching method. Goering and Burenheide (2010) write about

\footnotetext{
${ }^{1}$ The protest song's roles: Cultural role-these songs were reflected the culture of the oppressed. They usually showed where the people were and why they needed to fight the domination. Many songs infused culture, they had a cultural aspect. The dance and rhythm also reflected the culture. Political role-all liberation songs had a political message. They were didactic and showed the oppressed why they needed to shirk off the chains of bondage. Mobilizing role-linked to the political role of the song, there was the mobilising role. The songs' message wanted to reach as many people as possible-calling them to join the liberation struggle. Narrative role-many songs bore history; they recounted what happened in history. The narrative was contained in the political and the mobilising role of the song.
}

the need to utilize the Personal Practical Theory (PPT) in teaching subjects such as history. These authors point out that PPT involves an intense analytical look at one's own instructional practice and how a teacher can best enhance their instructional practice and their instruction so that all pupils can learn. Therefore, the use of songs in teaching is among the approaches that an educator can use to facilitate learning in the classroom. Using songs can be explored as one aspect to check what works well in classrooms. Goering and Burenheide (2010) also point out that there are three distinct phases for PPT:

- Identify what guides one's beliefs and actions;

- Analyze how these beliefs can best align to the content being taught; and

- Implement and reflect how this works in the classroom.

A teacher using songs as a form of PPT can see whether or not teaching is enhanced. The songs in a history classroom become part of the primary sources. Paras, Piche and Nillas (2004) state that if one considers the value placed on the pupils' understanding of history, primary sources can be used to deepen the pupils' understanding. It is also crucial to use the correct criteria in selecting these songs. Kramer (2001) points out that the text must fit the pupils' level; the singer's diction must be clear, so that the pupils can easily understand the lyrics and the songs must come from a variety of musical styles to 
afford opportunities to reach the widest possible audience.

This paper looks at teacher practice in a history classroom where the teacher teaching South Africa's struggle history uses the protest song as a primary source. The teacher mainly used songs composed by the South African Congress of Trade Union (SACTU) activist Vuyisile Mini. This trade unionist was also an African National Congress (ANC) member who was hanged by the apartheid government in November 1964. The main question asked was: What can educators and pupils learn in history classrooms where songs were used as primary sources?

\section{Pedagogy and Song in the Classroom}

Van der Merwe (2007) points out that theories of cognitive psychologists such as Bruner support the idea that knowledge and skills are synergistic and are established through integration, interrelationships and interconnectedness which increase learning. Songs and the arts should be accorded a place in all curricula to actualize this integration in the classroom. Kramer (2001) also writes about the benefits of using songs in the classroom. He points out that they offer mnemonic codes, such as repetition, rhyme, and melody that help the listener's memory. In the second language classroom songs have an even special value. "Since many students enjoy listening to songs in their native language, the teaching of songs in the foreign language (FL) classroom can help motivate students to learn” (Kramer, 2001). Brewer (1995) points out that the intentional use of songs in the classroom will set the scene and learning atmosphere to enhance the teaching and learning activities. Brewer lists a number of aspects that are accentuated by songs in classrooms and these include:

- Creating the desired atmosphere;

- Energizing the learning activities;

- Improving memory; and

- Enhancing imagination.

All these show that the songs can make learning effective. Carlson (2010) contends that the songs are able to make personal and world connections to the content studied. Moreover, the pupils are able to think critically about the issues raised by the content studied and song.

Levey and Byrd (2011) also cite White and Cormack (2006) who explain how music diminishes as pupils progress in grades at school. Levy and Byrd (2011: p. 64) writes:

However, they proposed that music has a definite application to the secondary education, social studies classroom. According to their article, older music can enhance understanding of history and contemporary songs can assist students in critically examining societal problems like "poverty, racism, abuse, and additions and such global issues as hunger, disease and war" (White \& McCormack, p. 122).

As history pupils listen to songs and sing songs they are guaranteed of active listening. Whitmer (2005) underscores this need to integrate songs into the lesson plan. She states that learners need to be taught active listening and songs can help the pupils set the scene. Moreover, the song can give the learners a multidimensional, perceptual, and interactive experience of history (Van Der Merwe, 2007). Heyning (2011) also perceives music as invaluable as a teaching tool which should be used across the curriculum because it addresses a number of aspects including differences in people; in aptitude, interest and inclination. Heyning (2013:22 aptly puts it, “children learn best about the world by listening, thinking, acting and integrating new experiences-experiential learning is the format in which we own our own learning whether we are a child or an adult”.

\section{The Study}

The study emanated from the history teacher's own action research. She had been reflecting on her use of music and songs in her history classrooms for more than four years. Action research is a strong tool for change and improvement at the local level (Cohen, Manion, \& Morrison, 2009). Action research has been used widely when teachers want to replace traditional methods by a discovery method. The researcher collected data through qualitative research methods where the history teacher's two secondary school classes were observed. Apart from a month's classroom observations, the researcher interviewed the teacher as well as ten learners. Three one hour classes were observed each week and the researcher was a non- participant observer. Among others, the observation schedule included observation of classroom participation, level of interest in the lesson, how the songs connect with the lesson, how the teacher utilized the songs. The researcher observed groups of pupils as they sang along some of the songs before discussions. He also listened to the group discussions as learners interpreted the lyrics trying to link them to particular events in history.

\section{Mini and the Freedom Song}

In her first lesson of introducing Mini's songs in her classrooms, the educator gave a brief historical background about the composer, demonstrating his pictures in the classroom and playing an audiotape of his last words before he was executed in November 1964. The teacher played an audio recording of a reader who was reading Mini’s written response to the apartheid police who were offering him and his two fellow accused clemency should they denounce the ANC struggle and work for the system instead. Mini wrote about this communication with the security branch in 1964:

I am presently awaiting execution at Pretoria Central Gaol having been sentenced to death at the beginning of the year. On October 2, 1964, Captain Geldenhuys and two other policemen came to see me. They asked if I had been informed that my appeal had been dismissed. I told them I was not interested to know from them what my advocate said. They then said there was still a chance for me to be saved as they knew I was the big boss of the movement in the Eastern Cape. I must tell them where the detonators and revolvers were, and they would help me. I refused. They then asked me about Wilton Mkwayi (subsequently sentenced to life imprisonment) and whether I was prepared to give evidence against Mkwayi whom they had now arrested, I said no, I was not. When they asked would I make the Amandla Ngawethu salute when I walked the last few paces to the gallows, I said yes.

Just this background or extract used by the teacher was enough to involve the pupils who immediately described the character of the writer of the above words. When the teacher first played the recording of the above words, there was silence which reflected pathos and in class. After the playback of this, the teacher asked the pupils to imagine to have met Mini and now they had to imagine as they talked about his personality. Each group presented a page on "the kind of a person Mini was". This was then followed by a 30 minutes discussion by the 
entire class. The teacher then introduced Mini's brief biography presenting it as a prologue to a series of lectures and talked about him as a composer of freedom or protest songs. The following is a summary that the teacher shared with the pupils.

Mini sang in a number of choirs in New Brighton, Port Elizabeth notably Port Elizabeth Male Voice Choir as well as the Port Elizabeth United Artists Choir which was conducted by the composer and celebrated author, Fikile Gwashu. He loved choral music as well as classical music. Among his many compositions, was the famous Naants'indod'emnyama Verwoerd. (Here comes the Black folk Verwoerd!). This is the song he is said to have sung on his way to the hangman's noose. In this song he was warning Verwoerd about the might of the black people. Hendrik Verwoerd was the South African Prime Minister in the 1960s. He is also referred to as "the architect of apartheid" who ensured that black people would be treated as second class citizens.

Many of Mini's songs were poignant but even with this sad tone, one gets the sense that the oppressed were fighting for a just cause. When Mini appeared in the political scene in the townships, he became very instrumental in organising people who were scattered. There was no better thing than to use his artistic talents to organize the community. He was also an able administrator, a secretary of the South African Congress of Trade Unions (SACTU) and worked closely with other struggle heroes such as Don Nangu and Alven Bennie. The SACTU and its affiliate unions enjoyed much support from the workers. "More than just a trade union to protect working class interests, it became an institution of and from the people" (Luckhardt \& Wall, 1980). Mini inspired the people with his singing and oratory. As a liberation fighter he was ahead of his times by realising that the song can organize and intensify the resistance against unjust laws.

\section{Collective Memory and Post-Apartheid South Africa}

Effective history teachers know that much oral history in the society is based on subjective accounts of people. They need to constantly relay this to their pupils as they teach them about apartheid memory. For teachers who were activists in particular, the autobiographical accounts can be an important source of teaching when used wisely. Coombes (2003) points out that all memory is unavoidably both borne out of individual subjective experience, shaped by collective consciousness and as shared social processes. Any comprehension of the representation of remembrances of the past must take into account both contexts (Coombes, 2003). Arguably, there is a need for South Africans to use memory in places such as the museums, understand and bring resolve to the trauma before moving towards the future as matured citizens. Many political activists in South Africa, although they were scarred by political repression, they have insisted on the productiveness of their years in detention and necessity of working toward a constructive future (Coombes, 2003). The traumatic memory and experience that can be ignited by some of the songs can actually result to a positive consequence; it can show the singer what freedom means. It can sensitize them in some way; that many people sacrificed, became martyrs for the freedom. These can be both empowering and emancipatory memories. Coming to terms with the past is one crucial aspect when it comes to dealing with history and memory in South Africa. Moving away from concentrating on oppression and atrocities of the past will never lead to liberated minds, and wounds will not be healed. The new cultural institutions such as museums have to deal with these facts. Liberation songs that highlight pain should remain in history as reminders of where the society is coming from. In the absence of leaders who had gone to exile, the struggle continued through song. Even after Mini's execution, his songs continued to live uniting the oppressed, creating a political culture that pervaded.

\section{The Experiences in the Classrooms}

The teacher in the study (we shall refer to her as Sindi) has been using history and songs for the previous four years after noting that her learners did not have much interest in the history subject area. She thought that the songs would interest her pupils. This is a strategy that was shunned upon by her (history) subject head who told her that the strategy would hardly work "with the kind of learners we have, instead it would confuse them as it shifts focus from what really matters". However, Sindi started with her novel teaching that supported transformative pedagogy in her grade 8 classes. This was her second year teaching grade 8 who were pupils coming from primary school. Many of her learners were daunted by the study of South African history in particular. She started using popular township music or $k_{w a i t o}{ }^{2}$ to relate historical events. She asked the learners to write their own kwaito songs as well. She was amazed when she heard from the English Second language teacher how this improved the pupils' language skills as well as their confidence. The pupils' historical knowledge also improved gradually because for the first time they were able to recollect events because they were linking these to certain songs.

In the grade 12 classes that Sindi was teaching, she was astounded to find how learners improved their grades in South African history. Sindi used the protest songs by Vuyisile Mini (Figure 1) to illustrate the plight of the black people's struggle for freedom in South Africa. Before focusing on specific songs that Sindi used, the concentration is on what the songs achieved in the pupils; one is critical thinking and the other is the transfer of learning.

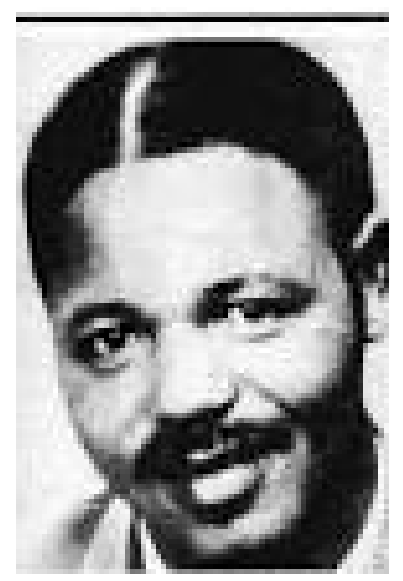

Figure 1.

Vuyisile mini. (Sechaba, 1969).

${ }^{2}$ Kwaito is a music genre that emerged in historically black areas in the 1990 s. There is a wide use of poetry and beat. It encompasses some of the qualities of house music and is very popular among the teens. 


\section{Critical Thinking and Emotional Experience}

Sindi spoke at length as to how the process of analyzing the lyrics of Mini's songs sharpened the pupils' critical thinking skills. This analysis enabled the pupils to get into the composer's mind and "see the world as he did decades before". This was a good exercise for constructivist learning which enabled the pupils to construct knowledge based on the songs. Moreover, this became part of the telling of her biography that she shared with the pupils. As they learnt about Mini, they were also learning about her times in the 1970s as a student activist their age.

The pupils mainly worked in groups as they listened to the songs and sung some whilst learning from their history texts. They were also excited about being able to discover Mini through his compositions as they learnt about the struggle's history. Paras et al. (2010) also underscore the role of primary sources that help pupils to think critically and analytically as this allows them to interpret events and question the various perspectives of history. It was also noteworthy to observe how the learners' working groups tried to see the events from various angles and possibilities. Vos (1999) argues that music does a number of things to pupils; it inspires emotion and can be used effectively to get pupils into an effective learning state.

As highlighted above, during observations of group discussions, the researcher noted how the pupils used the songs' lyrics and emotions evoked to interpret the historical events critically. Sindi's teaching was amenable to the post-apartheid system of education which requires learners who are critical thinkers. There are so many challenges in teaching that can make teachers forget about the learning aspect. Lujan and DiCarlo (2006: p. 17) contend:

Teaching is not telling students what we know but showing students how we learn. Learning is not commuting a set of facts to memory, but the ability to use resources to find, evaluate, and apply information. However, the curriculum is packed with so much content that, to "cover the content", teachers resort to telling students what they know and students commit facts to memory.

The history learning area can easily end up into telling methods. However, a teacher who is a critical thinker would be opposed to use these frequently, as she will want to instil a sense of understanding among learners as witnessed in this study. Critical teachers will transfer this vital skill to their learners. In fact, Yang (2012) argues that in order to foster critical thinking in learners, it is necessary to first nurture the teachers' critical thinking. The combinations of aspects such as assessment, critical reflection, are all factors that help in enhancing the teachers' skills in teaching. Fostering critical thinking is about the teachers' belief systems. "The influence of teacher belief and teacher experience in developing the ability to conduct critical thinking integrated instruction is profound, particularly given the diversity of student ability levels...” (Yang, 2012: p. 117).

In this study the pupils had to discuss the songs and events linked to these. They constantly had to employ their critical thinking skills as the teacher frequently employed the Socratic Method of questioning. Shelley (2009) writes about the closeness between the Socratic Method and critical thinking. This Socratic Method of questioning designed to help learners acquire, develop and retain knowledge through guidance rather than lecture. Shelley also argues about how group work pre- pares learners to the inevitability of collaboration in all aspects of adult life and specifically in the workplace. Group work helps elicit important factors for critical thinking and these are analysis, explanation, interpretation and self-regulation. All of these are what Facione (2013) refers to as core critical thinking skills. Of importance here is the transfer of learning.

\section{Transfer of Learning}

Hearing the songs in the history class enabled the pupils to be able to transfer learning. For learners to be able to transfer skills, they should first comprehend the subject. Lujan and DiCarlo (2006) emphasize that we must help learners become more active, independent learners and problem solvers, because active processing of information and not just passive reception of that information leads to learning. Transferring learning is easy when active learning strategies are employed. Active learning strategies reach all types of learners in visual, auditory, $\mathrm{read} /$ write, kinaesthetic and tactile schemes (Lujan \& DiCarlo, 2006). Facione (2013:p. 10) also argues:

The experts are persuaded that critical thinking is a pervasive and purposeful human phenomenon. The ideal critical thinker can be characterized not merely by her or his cognitive skills but also by how she or he approach3es life and living in general. This is a bold claim. Critical thinking goes way beyond the classroom.

Again, the expertise of the teacher is crucial in enhancing transfer of learning. There is a close connection between transfer of learning and problem solving. Yang (2012) points out that there is a link between critical thinking teacher training with classroom outcomes. Furthermore, Yang contends that there are three important features in the transfer of learning; task features, learner features and organizational features. All these have an impact on the transfer of learning. Task features have to do with the similarity of the learning task and target behaviour as well as opportunity for practice. Learner features include attitudes and dispositions. Organizational features include the design of teacher training programs and relationships among teacher education programs.

Mohammadi et al. (2013) point out that educators should respond to the following questions: What should be learned?

How to learn?

Why to learn?

These authors state that educators should put more emphasis on self-judgement and self-controlling issues. The latter is the basis of teaching children to be critical thinkers. Teachers must be aware of their professional growth as thinkers otherwise they will not be able to nurture thinkers who can be able to transfer learning. Mohammadi et al. (2013: pp. 654-655) postulate, “Teachers need to rethink about their role again focusing on their own activities on training skills because this leads to nurture students' critical thinking way". Critical thinking in classrooms depends on teacher readiness and professional accomplishment. A teacher needs to have attained best practices by gaining confidence as well as commitment to be able to use alternative and creative ways in class.

\section{Sindi's Classroom: Memory, the Song and the Subject of History}

As Sindi pointed out, the song accentuated critical thinking as it enabled memory. The pupils were able to create a relevant 
atmosphere they had never seen. The primary source of Mini's songs enabled them to visualize the experiences of history. The memory in the song made learning more meaningful to the pupils. Usually teachers of history argue that their pupils find history flat and uninspiring. However, as evident in this study, music has a potential to inject life into historical events. Paras, Piche and Nillas (2010) argue:

Historical songs were considered to be valuable primary sources as they provided students with "direct commentary, attitudes, and emotions expressed by real people in particular historical periods" (p.515). Therefore, the use of music as a primary source allowed for students to be engaged in historical learning. Binkiewicz also maintained that melodies and lyrics are natural means to remember material; though memorization is not a goal songs helped students imagine and remember historical concepts...

Sindi as well as the pupils pointed out how the songs made it easy for them to understand the context of many events. Vos (1999) contends that music is a powerful anchor that moors learning in memory. The latter is crucial for the history pupils in South Africa who study history in second or third language. Below, the focus is on a few songs used in the presence of the researcher where Sindi demonstrated the use of memory. Sindi demonstrated various roles that the protest song embraced. These are the cultural role, the political role, the mobilizing role and lastly the narrative role. The pupils were also able to find these in a number of songs.

Vuyisile Mini had compositions that fitted under these categories although many of his songs played a mobilising and political role. The song, Izakunyathel'iAfrika was one of the songs where he was addressing the apartheid leader Hendrik Verwoerd, the most famous being Naants'indod'emnyama Verwoerd cited above. The song Izakunyathela... (Loosely translated, Africa will trample on you), was composed in prison during the 1956 Treason Trial. The lyrics are as follows:

\begin{tabular}{|c|c|}
\hline $\begin{array}{l}\text { Izakunyathel’iAfrica, } \\
\text { Verwoerd }\end{array}$ & $\begin{array}{l}\text { Africa is going to trample } \\
\text { on you, Verwoerd }\end{array}$ \\
\hline Verwoerd shuu! & Verwoerd careful! \\
\hline Uzakwenzakala & You are going to get hurt. \\
\hline
\end{tabular}

There are a number of songs mentioning leaders such as Vorster, Strydom and many others. This showed the intense plea by the oppressed for these leaders to outlaw apartheid laws. Sindi played a number of similar songs whilst explaining and facilitating lessons on the defiance campaign in the 1950s. In fact, many of the songs she played were showing how the Defiance Campaign was strengthened. The Defiance Campaign was conceptualized by the ANC at a conference in Bloemfontein in 1951. The people wanted to do away with various segregation laws which included, pass laws, Group Areas Act, the Suppression of Communism Act. During this time the people were breaking all laws in a peaceful manner and were not even resisting arrest. Later though, it turned violent when police started shooting defiers. Many songs composed about Verwoerd illustrated how this apartheid mastermind was regarded by the oppressed. In another composition the Congress Volunteers in the 1950s tell Verwoerd in song to open prisons and free the political detainees. The song Sikhalel'izwe lakithi went like this:

\begin{tabular}{ll}
\hline $\begin{array}{l}\text { Sikhalel'izwe lakithi } \\
\text { Elathathwa ngabamhlophe }\end{array}$ & We mourn for our land \\
$\begin{array}{l}\text { MZulu MXhosa MSuthu } \\
\text { Hlanganani! }\end{array}$ & $\begin{array}{l}\text { Zulus, Xhosas Sothos unite! } \\
\text { Verwoerd, vula la majele }\end{array}$ \\
$\begin{array}{l}\text { SingamaVoluntiya sizongena } \\
\text { Verwoerd open these prisons }\end{array}$ & Else the volunteers will storm them. \\
\hline
\end{tabular}

When women marched to the Union Buildings in Pretoria 1956 they sang:

\begin{tabular}{ll}
\hline Wee Strydom! & You Strydom! \\
Wathint'abafazi, & You strike a woman, \\
Wathint'imbokotho, & You strike a rock, \\
Uzakufa & You will die. \\
\hline
\end{tabular}

Again this was Mini's composition. The women were protesting against a law which required women to carry passes like men did. They were disparaged, but the song was lifting them to be resilient. They did not march to kill Strydom. They were highlighting their plight and mobilizing one another. The songs were mighty in that even those people who were initially doubtful about their participation would see the spirit of a song and would go and confront the enemy; with song. The context of most of these songs captured the mood of the singers. Another Mini composition used in the classroom was Thath' umthwalo. He also composed this song when he was in prison during the treason trial in 1956. The treason trialists had been in prison for a long time when he composed this one:

\begin{tabular}{ll}
\hline $\begin{array}{l}\text { Thath'umthwalo bhuti } \\
\text { sigoduke }\end{array}$ & $\begin{array}{l}\text { Take up your luggage brother } \\
\text { and let’s go home }\end{array}$ \\
$\begin{array}{l}\text { Balindile oomama } \\
\text { noobab’ekhaya. }\end{array}$ & $\begin{array}{l}\text { Our mothers and fathers are } \\
\text { waiting back home }\end{array}$ \\
\hline
\end{tabular}

This was the nostalgic Mini. During the Defiance Campaign, many people were held behind bars and were longing for freedom. Mini was inspiring them to sing as they longed for home. Sometimes this nostalgia will show in song when the singers longed for the days before colonialism. One of the oldest songs is Thina sizwe esimnyama.... (We the Black Nation).

\begin{tabular}{ll}
\hline Thina sizwe & We the nation \\
Thina sizwe esimnyama. & The black nation, \\
Sikhalela, & We weep, \\
Sikhalela izwe lethu. & For our land. \\
Elarojwa, & Which was robbed, \\
Elarojwa ngamabhulu, & Robbed by the Boers. \\
Mabawuyeke, & They should leave \\
Mabawuyek'umhlaba wethu. & They should leave our land alone... \\
\hline
\end{tabular}

Another composition has a powerful message for the ANC's rise. The song was also sung widely in the 1950s when the ANC was organising in the Cape:

\begin{tabular}{ll}
\hline Mayihambe le Vangeli spread & Let this gospel \\
Mayigqib’ilizwe lonke world it & Around the whole should be heard \\
\hline
\end{tabular}


It was interesting to listen to the pupils singing some of these songs. Sindi asked them to write placards to carry around as groups sang these. The pupils told various stories about how they felt after moving around singing some of these songs. Some adjectives they used to describe their feelings were:

"Inspiring"

"Made me feel committed"

"Saddened me"

"Made me feel the pain"

"Left me feeling confused why there was segregation!"

Sindi talked about how she saw these songs as part of memory. She maintained that these songs, like the "new museums" and other monuments were explicating various aspects of heritage. She added that these were necessary for all the youth born in the post-apartheid South Africa.

\section{Memory and Heritage}

All the pupils saw the meaning of the protest song and understood its place not only in their learning area of history but in their heritage as well. It was interesting to see how the 1950s or the "Defiance Years" (as Sindi referred to them), were enacted. In fact, Sindi asked the groups to present defiance campaign in song which was enjoyed by the pupils as they recounted historical events. One group acted out a 15 minute musical drama enacting an event that happened in 1952 where Mini and other ANC volunteers were part of the defiers who walked through the New Brighton Railway Station in Port Elizabeth. In the actual event Mini and 30 volunteers walked through the "Europeans Only" entrance of the segregated New Brighton Station. They were accompanied by a crowd singing the song, 'What have we done, we African people?' the twenty five men and three women were all wearing (African National) Congress armbands and shouting, "Mayibuye iAfrica!" (Benson, 1985). The defiers had all intended to refuse to pay fines and go to prison instead. Sindi had earlier taught a lesson on this event. Roux (1964) writes that a newspaper report on 25 July stated that 32 defiance women had been sentenced for using the Europeans Only entrance at the New Brighton station near the Red Location. The report went on to declare:

Non-European defiers of unjust laws are being turned out of gaol against their will by the prison authorities. Money found on them at the time of their conviction has been seized and is being used to pay their fines, although they refused the option of a fine when sentenced.

They went to jail and as they traversed the road they defiantly sang:

\begin{tabular}{ll}
\hline Imithetho kaMalan & Malan’s laws, \\
Isiphethe nzima & Are oppressive. \\
Mayibuy'iAfrika! & Africa must come back! \\
\hline
\end{tabular}

The pupils enacted some of these songs in their simulation. Mini's songs were short, repetitive and melodious. He had an uplifting voice, his singing of his compositions spread throughout the South African provinces. In the discussion above we also "heard" his famous, Naants'indod'emnyama Verwoerd, which was also telling the government that despite the intensification of apartheid laws, the Africans were organizing. One composition that was sung in the townships from the 1950 s to the 1990 s and beyond was Sizakubadubula ngeembayi-mbayi (we will shoot them with cannons), whose lyrics were:

\begin{tabular}{ll}
\hline Sizakubadubula ngembayi-mbayi & We'll shoot them with cannons, \\
Bazobaleka, & They will flee, \\
Dubula ngembayi-mbayi & Shoot with cannons. \\
\hline
\end{tabular}

The pupils found it a powerful way of learning South Africa's struggle. In fact, they soon learnt to attach songs to various historical events of the defiance campaign. Sindi's use of the songs also demonstrated how history can be preserved using one aspect of memory. Deegan (2001) argues that a process needs to be found through which collective memory of the country could engage in recognising the tragedy of the past. She adds that it is only by looking back that a nation would be able to move towards normalized multiracial co-existence. Schools, like museums, can play a crucial role while starting off the memories there would be debates raised about issues as well. Schools and community museums should promote healthy discussions as people embrace democracy and a new future. The museums also need to strive for success where the society has not succeeded. Much oral history in the museum is based on subjective accounts of people. Sindi talked about this "inevitable symbiosis between a history class and museums today". Coombes (2003) points out that all memory is unavoidably both borne out of individual subjective experience and shaped by collective consciousness as well as shared social processes. Any comprehension of the representation of remembrances and of the past must take into account both contexts (Coombes, 2003). Arguably, there is a need for South Africans to use memory from oral accounts, from museums, understand and bring resolve to the trauma before moving towards the future as matured citizens. When one goes to New Brighton's Red Location Museum today, one sees an immense picture of Mini with a number of hangman's nooses behind; an intimidating and sad spectre. The traumatic memory and experience is ignited by these hangman's nooses but it results to a positive consequence; it can show the user what freedom really means. It can sensitize them in some way that many people sacrificed, became martyrs for the freedom. These can be both empowering and emancipatory memories. The perceiver is empowered through the understanding of history and it will be liberating as the users will understand their own purpose in history. The liberation songs can achieve the same.

\section{Conclusion}

The reflection by Sindi in her history classes was a topic of another paper and was not explored here. Yet, it can be highlighted that using music enabled Sindi to utilize her PPT as she looked at her instructional practice critically. She used music because she believed it would bring success to all her pupils. This article has also shown how history teachers can enhance aspects such as critical thinking, transfer of learning and memory whilst they try to raise learner success. Music has an appeal in classrooms because of its interdisciplinary nature. Teachers of all subjects can use music effectively if they select relevant songs for their subjects. This paper has also shown that the other advantage that music has is the influence on feelings, memory and enlivening the historical events. Music is also useful because it can be used in all classrooms by various age 
groups. Classrooms where music is used can also be fun because song enhances imagination and play; with these, it also improves the thought processes. Effective teachers will also choose songs to use in the classroom wisely. Some songs are more relevant than others depending on the themes taught. Good choice of songs will also support creative thinking among learners as they try to interpret the content.

\section{REFERENCES}

Benson, M. (1985). South Africa, the struggle for a birthright. London: IDAF.

Brewer, C. B. (1995). Music and learning: Integrating music in the classroom. New Horizons for Learning.

Carlson, J. R. (2010). Songs that teach: Using song-poems to teach critically. English Journal, 99, 65-71.

Cohen, L., Manion, L., \& Morrison, K. (2009). Research methods in education. London: Routledge.

Coombes, A. E. (2003). History after apartheid. Johannesburg: Wits University Press.

Deegan, H. (2001). The politics of the new South Africa: Apartheid and after. London: Pearson.

Dominy, G. (2004). The politics of museum collecting in the "old" and the "new" South Africa. In S. J. Knell (Ed.), Museums and the future of collecting (pp. 135-135). Aldershot: Ashgate.

Engh, D. (2013). Why use music in English language learning? A survey of the literature. English language Teaching, 6, 113-127.

Facione, P. A. (2013). Critical thinking: What it is and why it counts. Insight Assessment, 1-28.

Goering, C. Z., \& Burenheide, B. J. (2010). Exploring the role of music in secondary English and history classrooms through Personal Practical Theory. SRATE Journal, 19, 44.

Heyning, L. (2011). “I can’t sing!” The concept of teacher confidence in singing and the use within their classroom. International Journal of Education \& the Arts, 12, 1-28.

Kramer, D. J. (2001). A blueprint for teaching foreign languages and cultures through music in the classroom and on the web. ADFL Bulletin, 3, 29-35. http://dx.doi.org/10.1632/adfl.33.1.29

Levey, D. L., \& Byrd, D. C. (2011). Why can't we be friends? Using music to teach social justice. Journal of the Scholarship of Teaching and Learning, 11, 64-75.

Luckhardt, K., \& Wall, B. (1980). Organize...or starve! London: Lawrence and Wishart.

Lujan, H. L., \& DiCarlo, S. E. (2006). Too much teaching, not enough learning: What is the solution? Advances in Physiology Education, 30, 17-22. http://dx.doi.org/10.1152/advan.00061.2005

Mohammadi, R., Naderi, E., Shariyatmadari, A., \& Naraghi, M. S. (2013). The study of the effect of centralised planning system on the development of critical thinking in elementary school students. European Journal of Experimental Biology, 3, 654-660.

Paras, E., Piche, B., \& Nillas, L. (2010). Teaching and learning with primary sources: Research and practice. Teaching with Primary Sources, 2.

Roux, E. (1964). Time longer than rope: A history of the black man's struggle for freedom in South Africa. Madison: University of Wisconsin Press.

Shelley, A. E. (2009). Beyond buzz words and skill sets: The role of critical thinking in information literacy. Library Student Journal, 4, 1.

Van der Merwe, L. (2007). The "How To" of history teaching with and through music in the GET phase. Yesterday \& Today, 1 May 2007, 172-192.

Vos, J. (1999). An introduction to music revolution. Auckland: The Learning Web Limited.

Whitmer, M. (2005). Using music to teach American history. OAH Magazine of History, 4-6 July 2005.

http://dx.doi.org/10.1093/maghis/19.4.4 